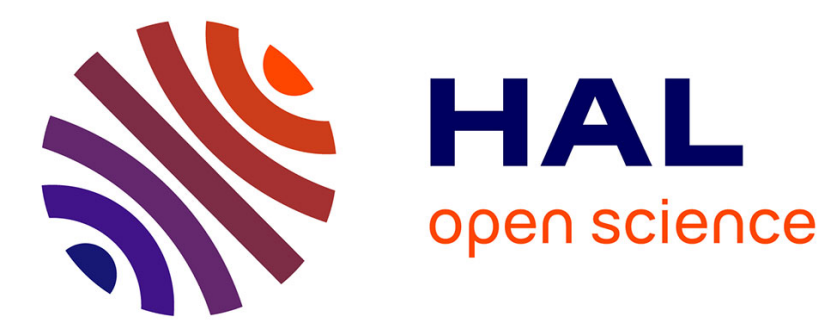

\title{
Therapeutic potential of CAMPATH-1H in skeletal tumours
}

\author{
Raphaela Fritsche, Andreas Grützkau, Aurelia Noske, Ingo Melcher, \\ Klaus-Dieter Schaser, Peter M Schlag, Hans U Kasper, Veit Jonas Krenn, \\ Christine Sers
}

\section{To cite this version:}

Raphaela Fritsche, Andreas Grützkau, Aurelia Noske, Ingo Melcher, Klaus-Dieter Schaser, et al.. Therapeutic potential of CAMPATH-1H in skeletal tumours. Histopathology, 2010, 57 (6), pp.851. 10.1111/j.1365-2559.2010.03722.x . hal-00601175

\section{HAL Id: hal-00601175 https://hal.science/hal-00601175}

Submitted on 17 Jun 2011

HAL is a multi-disciplinary open access archive for the deposit and dissemination of scientific research documents, whether they are published or not. The documents may come from teaching and research institutions in France or abroad, or from public or private research centers.
L'archive ouverte pluridisciplinaire HAL, est destinée au dépôt et à la diffusion de documents scientifiques de niveau recherche, publiés ou non, émanant des établissements d'enseignement et de recherche français ou étrangers, des laboratoires publics ou privés. 


\section{Histopathology}

Therapeutic potential of CAMPATH-1H in skeletal tumours

\begin{tabular}{|r|l|}
\hline Journal: & Histopathology \\
\hline Manuscript ID: & HISTOP-08-09-0450.R1 \\
\hline Manuscript Type: & Original Article \\
\hline Date Submitted by the \\
Author: & 17-Feb-2010 \\
\hline Kumplete List of Authors: & $\begin{array}{l}\text { Fritsche, Raphaela; Charite Universitätsmedizin Berlin, Institut of } \\
\text { pathology } \\
\text { Grützkau, Andreas } \\
\text { Noske, Aurelia } \\
\text { Melcher, Ingo } \\
\text { Schaser, Klaus-Dieter } \\
\text { Schlag, Peter } \\
\text { Kasper, Hans; Clemens-Hospital Münster, Institute of Pathology } \\
\text { Krenn, Veit } \\
\text { Sers, Christine; Institute of Pathology, Charité - } \\
\text { Universitätsmedizin Berlin }\end{array}$ \\
\hline Keywords: & $\begin{array}{l}\text { CD52, skeletal tumours, complement-dependent cytotoxicity, } \\
\text { osteosarcoma }\end{array}$ \\
\hline
\end{tabular}

\section{scholarONE" \\ Manuscript Central}




\section{Therapeutic potential of CAMPATH-1H in skeletal tumours}

Raphaela Fritsche-Guenther ${ }^{1}$, Andreas Gruetzkau ${ }^{2}$, Aurelia Noske ${ }^{1}$, Ingo Melcher ${ }^{3}$, Klaus-Dieter Schaser ${ }^{3}$, Peter M. Schlag ${ }^{4}$, Hans-Udo Kasper ${ }^{5}$, Veit Krenn ${ }^{6}$, Christine Sers $^{1}$

${ }^{1}$ Institute of Pathology, Charitè Universitätsmedizin Berlin, Berlin, Germany

${ }^{2}$ German Arthritis Research, Charitè Universitätsmedizin Berlin, Berlin, Germany

${ }^{3}$ Center for Musculoskeletal Surgery, Charitè Universitätsmedizin Berlin, Berlin, Germany

${ }^{4}$ Robert-Rössle-Klinikum, Charitè Universitätsmedizin Berlin, Berlin, Germany

${ }^{5}$ Institute of Pathology, University of Cologne, Cologne, Germany

${ }^{6}$ Center for Histology, Cytology and molecular Diagnostic, Wissenschaftspark Trier, Trier, Germany

\section{Corresponding Author:}

Dr. rer. nat. Raphaela Fritsche

Charitè Universitätsmedizin Berlin

Institute of Pathology

Chariteplatz 1

D-10117 Berlin

Fon: $\quad+4930450536157$

Fax: $\quad+4930450536909$

E-mail: $\quad$ raphaela.fritsche@charite.de 
Running title: $\quad$ CD52 in skeletal tumours

Keywords: CD52, skeletal tumours, complement-dependent cytotoxicity, osteosarcoma 


\begin{abstract}
Aim: CD52 is a GPI-anchored glycoprotein that is expressed abundantly on all lymphocytes, monocytes, macrophages, eosinophils and in the male genital tract. To date, the physiological role of CD52 on lymphocytes has not been elucidated. However, an antibody directed to CD52 called CAMPATH-1H has been shown to be capable of depleting lymphocytes. Tissue and cell lines of non-neoplastic bone, cartilage and skeletal tumours were analysed for CD52 expression. Methods and results: We detected the expression of the CD52 mRNA and protein both in vivo and in vitro. The malignant tumours showed a higher CD52 expression compared to the benign tumours, suggesting a role in the development and progression of bone tumours. Interestingly, immunohistochemistry and flow cytometry revealed that CD52 was not only expressed on the surface of the tumour cells, but also in the cytoplasm. Our results obtained in osteosarcoma cells show that CAMPATH-1H leads to a complement-independent reduction of viable cells. Conclusion: CD52 is expressed in a variety of bone tumours and the in vitro studies presented herein suggest that CAMPATH-1H treatment might have therapeutic potential for osteosarcoma patients with poor clinical prognosis.
\end{abstract}




\section{Introduction}

CD52 is a glycosylphosphatidylinositol (GPI)-anchored antigen, also called the CAMPATH-1H antigen. It is abundantly expressed on normal and malignant lymphocytes, such as cells from most B- and T-cell malignancies and in a minority of myeloid leukaemias on monocytes, macrophages and eosinophils ${ }^{1,2}$. In addition, CD52 can be found in the epithelial cells of the distal epididymis and the vas deferens and is acquired by sperm cells during their passage through the genital tract ${ }^{3}$. The structure of the CD52 protein is unusual. It is a very small, heavily glycosylated antigen with glycolipid-like properties. The sperm CD52 protein differs from the lymphocyte CD52 protein in its carbohydrate structure ${ }^{4}$. The physiological role of CD52 on lymphocytes is unclear. The high density of CD52 and the close proximity of the antibody binding site to the cell surface make it a particularly good target for therapeutic options ${ }^{5}$. These properties may contribute to the efficacy of the therapeutically used CD52 antibody, also called CAMPATH-1H (Alemtuzumab). CAMPATH-1H is capable of complementactivation and antibody-mediated cellular cytotoxicity leading to a depletion of lymphocytes ${ }^{6,7}$. Stanglmaier et al. also suggested a caspase-independent form of apoptosis that may be induced by CAMPATH-1H in patients with chronic lymphocytic leukaemia ${ }^{8}$. At present, CD52-specific antibodies are used to treat lympho-proliferative disorders like B-cell chronic lymphocytic leukaemia, to deplete lymphocytes in bone marrow transplants, in the therapy of transplant rejection, to control graft versus host disease and, most recently, to treat Behcet's disease and multiple sclerosis ${ }^{9-14}$.

By microarray analysis, we found that CD52 mRNA is significantly overexpressed in giant cell tumours of the bone ${ }^{15}$. Further experiments revealed a significant upregulation of CD52 mRNA in chondrosarcoma and osteosarcoma tissue samples, suggesting a previously unknown deregulation of CD52 in bone malignancies. 
The current study investigates levels of CD52 expression in skeletal tumours, especially in giant cell tumours, osteosarcoma and chondrosarcoma tissue and cell lines and their equivalent non-tumorous counterparts. The results imply a role for CD52 in the development and the progression of bone tumours. Furthermore, results obtained in osteosarcoma cells show that CAMPATH-1H leads to a reduction of viable cells. Therefore, CAMPATH-1H might have therapeutic potential for osteosarcoma patients with poor clinical prognosis.

\section{Material and Methods}

\section{Tissue studies}

\section{Patients and tissues}

Tumour tissue samples were obtained from the Institute of Pathology, Charitè Universitätsmedizin Berlin, Berlin, Germany and the Department of Pathology, University of Cologne, Cologne, Germany. Patient characteristics are described in Table 1. The tissue specimens were fixed in $4 \%$ neutral buffered formaldehyde, and bonecontaining tissue was EDTA decalcified and embedded in paraffin. For each case, hematoxylin and eosin (H\&E)-stained slides were carefully reviewed and the diagnosis of the tumour was confirmed according to the WHO criteria by two different pathologists. Tissue microarrays of bone $(n=4$ foetal and $n=6$ adult bone samples, each in duplicates; Cat. No. 4011211), cartilage ( $n=4$ embryonal, $n=6$ foetal and $n=10$ adult cartilage samples, each in duplicates; Cat. No. 4011223) and skeletal tumours ( $\mathrm{n}=3$ fibrosarcomas, $n=2$ osteosarcomas, $n=3$ chondrosarcomas, $n=1$ solitary bone cyst, $n=4$ aneurysmal bone cysts, $n=1$ fibrous dysplasia, $n=5$ chondromas, $n=5$ osteomas, $n=4$ osteochondromas, each in duplicates; Cat. No. 4132212) were obtained from Provitro $\mathrm{GmbH}$, Berlin, Germany. Written informed consent was obtained from each patient. 


\section{Immunohistochemistry}

Immunohistochemical analysis of CD52 was performed on 26 giant cell tumours $(n=18$ primary tumours, $n=8$ relapses), 14 osteosarcomas ( $n=7$ conventional, $n=7$ metastases) and 6 chondrosarcomas on paraffin-embedded microsections. Three tissue microarrays of cartilage, bone and skeletal tumours were stained for CD52 expression. Tissues were cut into 1-3 $\mu \mathrm{m}$ sections and deparaffinised through serial dilutions of alcohol. Retrieval of the CD52 antigen was performed by incubation with proteinase $\mathrm{K}$ (DAKO) and 0.05\% trypsine (Zymed). Anti-CD52 antibody (1:40 rat anti-human, Serotec), secondary antibody (1:40 rabbit anti-rat DAKO) and the APAAP complex (1:100 rat DAKO) were incubated for $30 \mathrm{~min}, 10 \mathrm{~min}$ and $10 \mathrm{~min}$ at room temperature, respectively. Fuchsin ${ }^{+}$ (DAKO) was used as the chromogen. Nuclear counter staining was performed with haemalum. Negative control sections were not incubated with the primary antibody and in no case showed evidence of staining with colour reactions under microscopic examination.

The staining of all cases was semi-quantitatively scored by two different observers using the following method modified from Remmele and Stegner ${ }^{16}$ : 1. A score to measure the percentage of positively stained cells $(\mathrm{PP})$ was performed as follows: $0=$ no staining, $1=1-25 \%, 2=26-50 \%, 3=51-75 \%, 4=76-100 \%$. 2 . A staining intensity score (SI) was established to measure the intensity of positively stained cells: $0=$ no expression, 1 = weak expression, 2 = moderate expression, $3=$ strong expression. The combined immunoreactivity score (IRS) value was calculated through PPXSI with a maximum value of 12 . Statistical analyses were performed executing the MannWhitney-U-Test using SPSS 13.0 software. Differences were considered significant at $\mathrm{p}<0.05$. 


\section{In vitro studies}

\section{Cells and cell culture}

Primary cultures of osteoblasts $(\mathrm{HOBc})$ and chondrocytes were purchased from Provitro $\mathrm{GmbH}$, Berlin, Germany and cultured in special osteoblast growth medium (PromoCell, Heidelberg, Germany) or RPMI1640 media (Biochrom) supplemented with 10\% foetal calf serum and $1 \%$ penicillin/streptomycine, respectively. The cell line Hut78 was obtained from the ATCC (American Type Culture Collection, United Kingdom) and cultured in RPMI1640 media (Biochrom) supplemented with $10 \%$ foetal calf serum and $1 \%$ penicillin/streptomycine. The osteosarcoma cell line MNNG/HOS was a gift from Prof. Dr. G. Gaedicke, Clinic for General Paediatrics and Experimental Oncology Charitè Universitätsmedizin Berlin, Berlin, Germany. The cells were maintained in RPMI1640 media (Biochrom) supplemented with $10 \%$ foetal calf serum and $1 \%$ penicillin/streptomycine. The chondrosarcoma cell line $\mathrm{AD}$ was a gift from Dr. $\mathrm{T}$. Aigner, Institute of Pathology, Friedrich-Alexander University Erlangen, Erlangen, Germany. For the establishment of a human giant cell tumour primary culture, resection tissue (male, 28 years) was minced in dispase-collagenase with PBS (phosphate buffered saline) and incubated for $20 \mathrm{~min}$ at $37^{\circ} \mathrm{C}$. After that the cells were resuspended in Leibowitz L15 medium (Lonza) and, together with small tissue fragments, were then transferred to $75-\mathrm{cm}^{2}$ flasks for subsequent culturing. Half of the medium was changed on the second day. All cells were incubated in a humidified atmosphere of $5 \% \mathrm{CO}_{2}$ in air at $37^{\circ} \mathrm{C}$.

\section{Flow cytometry}

Direct fluorescein isothiocyanate (FITC)-conjugated rat anti-human CD52 antibody (1:10 Serotec) and FITC-conjugated IgG (1:50 Pharmingen) were used for flow 
analyses of Hut78, HOBc, MNNG/HOS, chondrocytes, AD and giant cell tumour cell lines. The flow cytometry was performed by staining the cells with the FITC-conjugated antibody in PBS containing 1\% BSA (bovine serum albumine) and $0.2 \%$ Saponin for intracellular staining and in PBS containing 1\% BSA for membranous staining for 30 min. Prior to the intracellular staining the cells were treated with $8 \%$ paraformaldehyde for $15 \mathrm{~min}$ at $37^{\circ} \mathrm{C}$ for fixation. Cells were analysed using a FACScan (BectonDickinson).

\section{Proliferation assay}

MNNG/HOS cells were plated in 96-well-plates and treated with $10-1,000 \mu \mathrm{g} / \mathrm{ml}$ CAMPATH-1H (Schering) for up to $96 \mathrm{~h}$. For complement-mediated cytotoxicity, $10 \%$ human complement was added to the media. For the control, the complement was heatinactivated for $1 \mathrm{~h}$ at $56^{\circ} \mathrm{C}$. Proliferation of cells was measured using the MTT cell proliferation kit from Roche.

\section{Immunoblot}

Protein extracts of MNNG/HOS cells were prepared by incubation with sodium dodecylsulfate (SDS)-cell lysis buffer (10\% SDS, 1M Tris-HCl pH 7.5, EDTA $0.5 \mathrm{M}$ $\mathrm{pH}$ 8). Reagents for SDS-PAGE and Western blotting were obtained from Bio-Rad Laboratories (Richmond, CA). Electrophoresis was performed and the proteins were transferred onto nitrocellulose membranes (Schleicher \& Schüll). Unbound protein sites were blocked with 5\% milk powder in Tris-buffered saline containing 0.01\% Tween-20 (TBST). Thereafter, specific proteins were detected by incubation with mouse antihuman PARP (1:500 BD) and mouse anti-human actin (1:5,000 Chemicon) antibodies 
overnight at $4^{\circ} \mathrm{C}$ followed by HRP-conjugated rabbit anti-mouse (1:5,000 Dianova) secondary antibody. Blots were developed using the ECL system from Amersham.

\section{Results}

\section{Tissue studies}

\section{Increased CD52 expression in bone malignancies}

RNA derived from eight osteosarcoma samples ( $n=4$ conventional, $n=4$ metastases) and from the human osteoblast primary culture $\mathrm{HOBc}$ was analysed using Affymetrix HG U133A microarrays (GEO accession number GSE14359; Guenther et al. submitted). A significantly higher expression of CD52 was found in osteosarcoma metastases as compared to conventional osteosarcoma ( $\mathrm{p}=0.000619)$. CD52 mRNA levels were below background in $\mathrm{HOBc}$ cells and the conventional osteosarcomas, except for in the OS18 cell line (relative expression level of 1,022 and 1,336). In the microarray analysis of primary and recurrent giant cell tumours of bone, CD52 mRNA was lower in recurrent as compared to primary giant cell tumours ${ }^{15}$.

For the validation of microarray data, 14 osteosarcoma tissue samples $(n=7$ conventional and $n=7$ lung metastases) and 26 giant cell tumour tissue samples ( $n=18$ primary, $n=8$ recurrence) were stained for CD52. As a control, a tissue microarray of non-neoplastic bone samples containing 4 foetal and 6 adult samples was used. High levels of CD52 protein were seen in foetal bone (Fig. 1A), while adult bone had lower CD52 levels (Fig. 1B). Interestingly, the osteoblasts in foetal bone samples showed the strongest CD52 staining, while the osteoblasts in adult bone were CD52 negative or showed only weak expression of CD52. We also found a largely cytoplasmic localisation, with only rare cases having a nuclear expression pattern of CD52 protein. The osteocytes were CD52 positive in foetal and adult bone (Fig. 1A, B). The primary 
osteoblast cells $\mathrm{HOBc}$ did not express CD52 protein, consistent with our Affymetrix mRNA data (Fig. 1C). All ostoesarcoma samples showed a strong immunoreactivity for the CD52 antigen (IRS 6.1), but no significant differences could be observed between the conventional osteosarcomas and the metastases $(\mathrm{p}=0.515)$. The latter showed generally a lower CD52 expression (IRS=5.6) as compared to the conventional osteosarcomas (IRS=6.6). In most cases, the CD52 staining was cytoplasmic, but some nuclear localisation could also be observed (Fig. 1D).

CD52 protein was detected in $18 / 18$ primary giant cell tumours and 8/8 recurrence samples. The macrophage-like cells and the multinucleated giant cells showed on average a moderate cytoplasmic staining intensity (Fig. 1E).

\section{High expression of CD52 in chondrosarcoma and cartilage}

CD52 protein expression was also tested in non-neoplastic and neoplastic cartilage samples. The non-neoplastic tissue microarray included 4 embryonal, 6 foetal and 10 adult cartilage tissue samples, and the neoplastic tissue array had 6 chondrosarcoma tissue samples. Non-neoplastic cartilage was CD52 negative in all embryonal (Fig. 2A) and in $4 / 5$ foetal cartilage samples (Fig. 2B). Only one foetal cartilage tissue had low CD52 expression. In contrast, CD52 expression could be observed in chondrocytes of adult cartilage by immunohistochemistry (Fig. 2C). Furthermore, a primary chondrocyte culture showed a low cytoplasmic CD52 expression (Fig. 2D). The chondrosarcoma tissue samples had the highest IRS (IRS 7.3) compared to osteosarcomas (IRS 6.1) and giant cell tumours (6.2). In total, 76-100\% of the chondrosarcoma cells were positive $(\mathrm{PP}=3.8)$ with an average staining intensity of 2.1 . The grade 2 chondrosarcomas showed a moderate cytoplasmic expression of CD52, whereas in the grade 3 samples a strong cytoplasmic CD52 staining could be observed (Fig. 2E). Because of the small 
sample number, no statistically significant correlation between protein intensity and tumour grade could be shown.

\section{$\underline{\text { CD52 expression is rare in skeletal tumours }}$}

In addition to osteosarcoma, chondrosarcoma and giant cell tumours, benign bone- and cartilage-related, malignant fibrous and skeletal tumours with undefined origin (fibrous dysplasia and aneurysmal bone cyst) were analysed for CD52 expression. Results from immunohistochemical evaluation of all skeletal tumours are shown in Table 2. Cytoplasmic and nuclear CD52 expression could be detected in 4/5 benign chondromas (Fig. 3A), 2/3 benign osteochondromas (Fig. 3B), 3/3 malignant fibrosarcomas (Fig. 3C), 3/3 benign aneurysmal bone cysts (Fig. 3D) and 5/5 benign osteomas (Fig. 3E). Fibrous dysplasia stained weakly and CD52 protein was only detected in the stroma (Fig. 3F).

\section{In vitro studies}

\section{Membranous and intracellular localisation of CD52}

Immunohistochemical staining suggested a dual localisation of CD52 both on the surface of the cells, as expected for GPI-anchored glycoproteins, but also in the cytoplasm. To analyse the intra- and extracellular expression of CD52, flow cytometric analysis was performed using the CD52 FITC-conjugated antibody in osteosarcoma and chondrosarcoma cell lines, giant cell tumour and chondrocyte and osteoblast primary cultures (Table 3, Fig. 4). The human T-cell lymphoma cell line Hut78 was included as a positive control due to known expression of $\mathrm{CD} 52^{17}$.

Staining of Hut78 for membranous and intracellular CD52 revealed $32 \%$ and 93\% positive cells, respectively (Fig. 4A). In MNNG/HOS osteosarcoma cells, $10 \%$ of cells showed a membranous staining, while 69\% showed an intracellular staining (Fig. 
4C). The chondrosarcoma cell line $\mathrm{AD}$ contained $74 \%$ positive cells, the highest proportion of CD52 positive cells (Fig. 4E). The highest membranous expression could be detected in the giant cell tumour primary culture, with $20 \%$ positive stained cells (Fig. 4F).

\section{CAMPATH-1H inhibits growth of osteosarcoma cells}

The therapeutic CD52 antibody CAMPATH-1H was shown to deplete lymphocytes through antibody-dependent cytotoxicity or complement-dependent cytotoxicity. To study the effect of the CAMPATH-1H antibody on bone tumours, we incubated the human osteosarcoma cell line MNNG/HOS with $50 \mu \mathrm{g} / \mathrm{ml}$ or $100 \mu \mathrm{g} / \mathrm{ml}$ CAMPATH$1 \mathrm{H}$ and assayed for cell growth.

Using $50 \mu \mathrm{g} / \mathrm{ml}$ and $100 \mu \mathrm{g} / \mathrm{ml}$ CAMPATH-1H in media containing $10 \%$ human complement, a significant reduction of proliferating MNNG/HOS cells was observed when compared to cells incubated with inactive complement $(50 \mu \mathrm{g} / \mathrm{ml} \mathrm{p}=0.026,100$ $\mu \mathrm{g} / \mathrm{ml} \mathrm{p}=0.021$; Fig. $5 \mathrm{~A}$ ). To test the specificity of CAMPATH-1H, the same assay was performed in the absence of human complement. This assay demonstrated a dose- (Fig. 5B) and time-dependent (Fig. 5C) reduction of viable MNNG/HOS cells compared to untreated control cells. To determine whether CAMPATH-1H induces apoptosis, we performed Western blot analysis for cleaved PARP. Apoptosis leads to cleavage of the $116 \mathrm{kDa}$ native PARP protein to an $85 \mathrm{kDa}$ fragment. In MNNG/HOS CAMPATH-1H treated cells, no cleaved PARP product was observed, suggesting an apoptosisindependent mechanism of cell growth inhibition (Fig. 5D). 


\section{Discussion}

CAMPATH-1H, also known as Alemtuzumab, belongs to the CAMPATH-family of antibodies that recognises CD52. The CD52 antigen is highly expressed on lymphocytes, monocytes, eosinophils and in the male reproductive $\operatorname{tract}^{3}$. The function of CD52 is still unknown. Nevertheless, the CAMPATH-1H antibody is effective in the treatment of chronic lymphocytic leukaemia ${ }^{18}$. Our current work shows for the first time that CD52 is also expressed in non-neoplastic and neoplastic bone- and cartilage-related mesenchymal cells, suggesting a role in bone or cartilage development and progression.

We found high CD52 levels in malignant tumours like chondrosarcoma and osteosarcoma but lower expression in benign and semimalignant tumours. Interestingly, the cartilage-forming tumours showed the highest expression of CD52. A high level of CD52 protein was detected in non-neoplastic cartilage and the benign tumours osteochondroma and chondroma, and an even stronger staining was found in chondrosarcoma. Based on these observations we suggest that CD52 expression in bone tumours correlates with the degree of malignancy. However, due to the small sample number, no statistical correlation between protein intensity and tumour grade could be shown. This observed upregulation of CD52 expression is consistent with reported increased levels of soluble CD52 in patients with chronic lymphatic leukaemia ${ }^{19}$.

CD52 was also strongly expressed in foetal reactive bone, while quiescent adult bone cells showed weak or no expression of the CD52 antigen. High expression of CD52 in osteosarcoma suggests the reactivation of an embryonic program in these tumours. One of the best known examples indicating the reactivation of embryonic genes in tumours is the expression of the carcinoembryonic antigen (CEA). CD52 and CEA share several properties; for example, patients with osteosarcoma show an increased serum level of $\mathrm{CEA}^{20}$. Comparable to CEA, soluble CD52 was also found in 
the serum of patients with chronic lymphatic leukaemia, indicating that a potential shedding of CD52 might also occur in osteosarcoma cells ${ }^{19,}{ }^{21}$. These observations suggest that soluble CD52 may act as a tumour marker for chronic lymphatic leukaemia, because increased CD52 levels correlate with aggressive stages of the disease. Whether CD52 can potentially also be used as a tumour marker in the serum of patients with osteosarcoma has yet to be determined.

Microarray analysis of osteosarcoma tissue suggested a significantly higher CD52 expression in lung metastases of osteosarcomas as compared to conventional osteosarcomas. In contrast, the microarray analysis of primary and recurrent giant cell tumours of the bone showed a significantly higher expression of CD52 in primary tumours as compared to the recurrent ${ }^{15}$. These differences could not be verified using immunohistochemistry. The differential expression of CD52 was based on variable fractions of lymphocytes and bone tumour cells. For example, in the osteosarcoma metastases, more monocytes and macrophages could be detected than in the conventional osteosarcomas (data not shown) leading to an artificially increased CD52 mRNA level. In the giant cell tumour recurrent tissue, decreased macrophages and lymphocytes were detected as compared to the primary tumours, leading to an artificial decrease in CD52 expression.

Interestingly, an intracellular expression of CD52 flow cytometry could be detected. In a previous study, the GPI-anchored protein EFNA1 was also shown to be expressed intracellularly, which could be due to abnormalities in GPI-anchor biosynthesis or failure of GPI transport resulting in an intracellular localisation of CD52. Nevertheless, CAMPATH-1H was able to deplete osteosarcoma cells in vitro with and without complement. Based on these results, further studies are warranted to 
determine whether CAMPATH-1H could be a therapeutic option to treat patients with osteosarcoma tumours. 


\section{References}

1. Hale G, Xia M, Tighe H, Dyer M, Waldmann H. The CAMPATH-1 antigen (CDw52). Tissue Antigens 1990;35;118-127.

2. Elsner J, Hochstetter R, Spiekermann K, Kapp A. Surface and mRNA expression of the CD52 antigen by human eosinophils but not by neutrophils. Blood $1996 ; 88 ; 4684-4693$.

3. Kirchhoff C. CD52 is the 'major maturation-associated' sperm membrane antigen. Mol Hum Reprod 1996;2;9-17.

4. Schroter S, Derr P, Conradt HS, Nimtz M, Hale G, Kirchhoff C. Male-specific modification of human CD52. J Biol Chem 1999;274;29862-29873.

5. Bindon $\mathrm{C}$, Hale $\mathrm{G}$, Waldmann $\mathrm{H}$. Importance of antigen specificity for complement-mediated lysis by monoclonal antibodies. Eur J Immunol. 1988;18;15071514.

6. Heit $\mathrm{W}$, Bunjes $\mathrm{D}$, Wiesneth $\mathrm{M}$ et al. Ex vivo T-cell depletion with the monoclonal antibody Campath-1 plus human complement effectively prevents acute graft-versus-host disease in allogeneic bone marrow transplantation. Br J Haematol $1986 ; 64 ; 479-486$.

7. Xia MQ, Hale G, Waldmann H. Efficient complement-mediated lysis of cells containing the CAMPATH-1 (CDw52) antigen. Mol Immunol 1993;30;1089-1096.

8. Stanglmaier M, Reis S, Hallek M. Rituximab and alemtuzumab induce a nonclassic, caspase-independent apoptotic pathway in B-lymphoid cell lines and in chronic lymphocytic leukemia cells. Ann Hematol 2004;83;634-645.

9. Waldmann H, Polliak A, Hale $\mathrm{G}$ et al. Elimination of graft-versus-host disease by in-vitro depletion of alloreactive lymphocytes with a monoclonal rat anti-human lymphocyte antibody (CAMPATH-1). Lancet 1984;2;483-486. 
10. Giralt S. The role of alemtuzumab in nonmyeloablative hematopoietic transplantation. Semin Oncol 2006;33;S36-43.

11. Magliocca JF, Knechtle SJ. The evolving role of alemtuzumab (Campath-1H) for immunosuppressive therapy in organ transplantation. Transpl Int 2006;19;705-714.

12. Cox AL, Thompson SA, Jones JL et al. Lymphocyte homeostasis following therapeutic lymphocyte depletion in multiple sclerosis. Eur J Immunol 2005;35;33323342.

13. Lockwood CM, Hale G, Waldman H, Jayne DR. Remission induction in Behcet's disease following lymphocyte depletion by the anti-CD52 antibody CAMPATH 1-H. Rheumatology (Oxford) 2003;42;1539-1544.

14. Dearden CE. Alemtuzumab in lymphoproliferate disorders. Rev Clin Exp Hematol 2002;6;435-448; discussion 449-450.

15. Guenther R, Krenn V, Morawietz L et al. Giant cell tumours of the bone: molecular profiling and expression analysis of Ephrin A1 receptor, Claudin 7, CD52, FGFR3 and AMFR. Pathol Res Pract 2005;201;649-663.

16. Remmele W, Stegner H. Recommendation for uniform definition of an immunoreactive score (IRS) for immunohistochemical estrogen receptor detection (ERICA) in breast cancer tissue. Pathologe 1987;8;138-140.

17. Rebello P, Hale G. Pharmacokinetics of CAMPATH-1H: assay development and validation. J Immunol Methods 2002;260;285-302.

18. Osterborg A, Fassas AS, Anagnostopoulos A, Dyer MJ, Catovsky D, Mellstedt H. Humanized CD52 monoclonal antibody Campath-1H as first-line treatment in chronic lymphocytic leukaemia. Br J Haematol 1996;93;151-153. 
19. Albitar M, Do KA, Johnson MM et al. Free circulating soluble CD52 as a tumour marker in chronic lymphocytic leukemia and its implication in therapy with anti-CD52 antibodies. Cancer 2004;101;999-1008.

20. Cortes EP, Chu TM, Wang JJ, Holyoke D, Wallace HJ, Murphy GP. Carcinoembryonic antigen in osteosarcoma. J Surg Oncol 1977;9;257-265.

21. Giles FJ, Vose JM, Do KA et al. Circulating CD20 and CD52 in patients with non-Hodgkin's lymphoma or Hodgkin's disease. Br J Haematol 2003;123;850-857. 


\section{Tables}

Table 1: Patient samples of tissues used for immunohistochemical analyses.

\begin{tabular}{|c|c|c|c|c|c|}
\hline \multicolumn{2}{|l|}{ Tumour } & \multicolumn{2}{|l|}{ Type } & \multirow[t]{2}{*}{ Mean age } & \multirow[t]{2}{*}{ Gender } \\
\hline Bone & $n=10$ & foetal & $n=4$ & & \\
\hline & & adult & $n=6$ & 68.2 & $\begin{array}{l}n=1 \text { male } \\
n=5 \text { female }\end{array}$ \\
\hline \multirow[t]{2}{*}{ Osteosarcoma } & $n=14$ & conventional & $n=7$ & 42.6 & $\begin{array}{l}n=5 \text { male } \\
n=2 \text { female }\end{array}$ \\
\hline & & metastases & $n=7$ & 39.4 & $\begin{array}{l}n=4 \text { male } \\
n=3 \text { female }\end{array}$ \\
\hline \multirow[t]{3}{*}{ Cartilage } & $n=20$ & embryonal & \multicolumn{3}{|l|}{$n=4$} \\
\hline & & foetal & \multicolumn{3}{|l|}{$n=6$} \\
\hline & & adult & $\mathrm{n}=10$ & 69.2 & $\begin{array}{l}n=6 \text { male } \\
n=4 \text { female }\end{array}$ \\
\hline Chondrosarcoma & $\mathrm{n}=8$ & & & $\begin{array}{c}48.5 \\
\\
\end{array}$ & $\begin{array}{l}n=7 \text { male } \\
n=1 \text { female }\end{array}$ \\
\hline \multirow[t]{2}{*}{ GCT } & $n=26$ & primary & $n=18$ & 39.8 & $\begin{array}{l}n=9 \text { male } \\
n=9 \text { female }\end{array}$ \\
\hline & & recurrence & $n=8$ & 42.9 & $\begin{array}{l}\mathrm{n}=4 \text { male } \\
\mathrm{n}=4 \text { female }\end{array}$ \\
\hline Osteoma & \multicolumn{3}{|l|}{$\mathrm{n}=5$} & 38.2 & $\begin{array}{l}n=3 \text { male } \\
n=2 \text { female }\end{array}$ \\
\hline Osteochondroma & $n=3$ & & & 21.6 & $\begin{array}{l}n=1 \text { male } \\
n=2 \text { female }\end{array}$ \\
\hline Chondroma & $\mathrm{n}=5$ & & & 65.0 & $\mathrm{n}=5$ female \\
\hline
\end{tabular}




\begin{tabular}{|l|l|l|l|}
\hline Fibrosarcoma & $\mathrm{n}=3$ & 48.3 & $\mathrm{n}=3$ male \\
\hline Aneurysmal & $\mathrm{n}=3$ & 24.3 & $\mathrm{n}=2$ male \\
bone cyst & & $\mathrm{n}=1$ female \\
\hline Fibrous & $\mathrm{n}=1$ & 60 & male \\
\hline
\end{tabular}


Table 2: Immunohistochemical analyses of skeletal tumours. CD52-negative and CD52positive tissue staining and the staining intensity (+: low, ++: medium, +++: strong) was calculated for each sample.

\begin{tabular}{|l|l|l|l|l|}
\hline \multirow{2}{*}{ Origin } & \multirow{2}{*}{ Tumour } & Type & Classification & expression \\
\hline Cartilage & Chondroma & Enchondroma & Benign & $\mathbf{1 / 1}++$ \\
\cline { 3 - 5 } & & Periostal & Benign & $\mathbf{3 / 4}+$ \\
\cline { 2 - 5 } & Osteochondroma & Benign & $\mathbf{2 / 3}+$ \\
\cline { 2 - 5 } & Chondrosarcoma & Malignant & $\mathbf{6 / 6}+++$ \\
\hline Bone & Osteoma & Benign & $\mathbf{5 / 5}+$ \\
\cline { 2 - 5 } & Osteosarcoma & Malignant & $\mathbf{1 4 / 1 4 + + +}$ \\
\hline Fibrous & Fibrosarcoma & Malignant & $\mathbf{3 / 3 + + +}$ \\
\hline Undefined & Fibrous dysplasia & Benign & $\mathbf{1 / 1}+$ \\
\cline { 2 - 5 } & Aneurysmal bone cyst & Benign & $\mathbf{3 / 3 +}$ \\
\hline GCT & & Semimalignant & $\mathbf{2 6 / 2 6 + +}$ \\
\hline
\end{tabular}


Table 3: Membranous and intracellular expression of CD52 analyzed by flow cytometry. \%:

Percentage of CD52 positive cells. GCT: Giant cell tumour primary culture.

\begin{tabular}{|l|l|l|l|l|l|l|}
\hline \multirow{2}{*}{} & \multicolumn{2}{|l}{ Membranous } & \multicolumn{2}{l|}{ Intracellular } \\
\cline { 2 - 7 } & \% IgG & \% CD52 & \% IgG-CD52 & \% IgG & \% CD52 & \% IgG-CD52 \\
\hline Hut78 & 2.0 & 34.2 & 32.2 & 2.3 & 94.9 & 92.6 \\
\hline HOBc & 0.3 & 0.5 & 0.2 & 0.3 & 0.4 & 0.1 \\
\hline MNNG/HOS & 0.1 & 9.9 & 9.8 & 0.1 & 69.0 & 68.9 \\
\hline Chondrocytes & 1.7 & 2.9 & 1.2 & 1.2 & 8.0 & 6.8 \\
\hline AD & 2.0 & 3.3 & 1.3 & 0.7 & 74.4 & 73.7 \\
\hline GCT & 5.3 & 25.0 & 19.7 & 4.7 & 54.9 & 50.2 \\
\hline
\end{tabular}




\section{Figure legends}

Figure 1: A: CD52 protein expression in human fetal bone. The osteocytes (blue arrow) and the osteoblasts (black arrow) were CD52 positive. B: No or weak CD52 staining in human adult bone osteoblasts (black arrow), while a CD52-expression is observed in the osteocytes (blue arrow). C: HOBc osteoblast cells are CD52 negative. D: CD52expressing tumor cells in a high grade conventional osteosarcoma. E: CD52-expression in giant cell tumors of bone. Most of the cells (including multinuclear giant cells, mononuclear-like cells, fibroblast-like cells and matrix) were CD52-positive, while also negative cells could be detected (arrow). So we excluded general background staining. F: Heightened picture of the CD52-negative multinucleated giant cell of E.

Figure 2: Human embryonal cartilage is negative for CD52 (A); also human fetal cartilage does not express CD52 (B). Adult cartilage expresses the CD52 antigen (C). Low CD52-expression in the primary culture of chondrocyte cells (D) and a strong CD52-expression in chondrosarcoma tumor cells (E).

Figure 3: Chondroma (A), osteochondroma (B), fibrosarcoma (C), aneurysmal bone cyst (D), osteoma (E) and fibrous dysplasia (F) express the CD52 antigen.

Figure 4: A-F: Cells were analyzed for surface (mebranous) and cytoplasmic (intracellular) expression of CD52 by flow cytometry. The black curve represent cells stained with the CD52:FITC antibody, the grey curve represents the isotype control staining (IgG:FITC). 
Figure 5: Complement-dependent (A), dose- $(\mathbf{B})$ and time-dependent $(\mathbf{C})$ reduction of cell growth through CAMPATH-1H. D: Western blot analysis was performed to detect cleavage of PARP. MNNG/HOS cells were treated with $50 \mu \mathrm{g} / \mathrm{ml}$ CAMPATH-1H up to three days, afterwards PARP cleavage was tested. 


\section{Figure 1A-E}
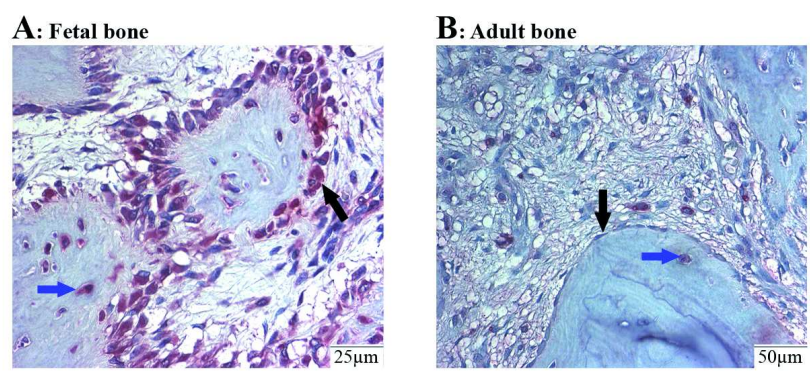

C: Osteoblast primary culture HOBc
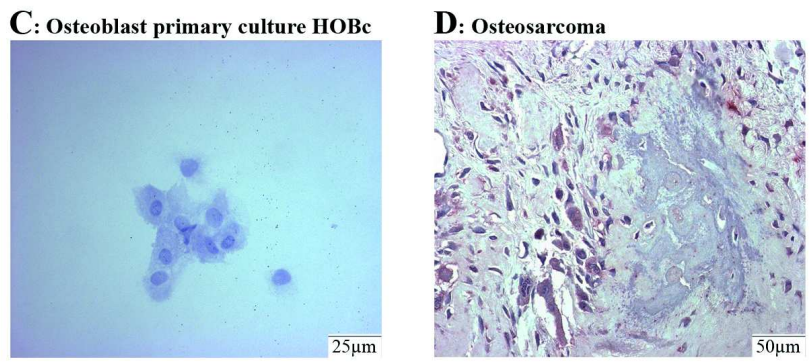

E: Giant cell tumor

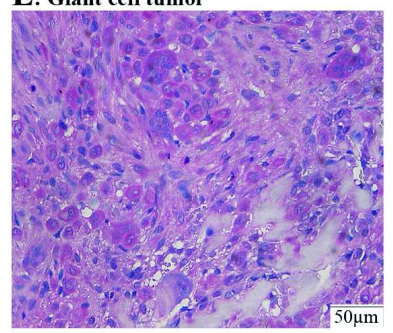

$210 \times 295 \mathrm{~mm}(200 \times 200 \mathrm{DPI})$ 


\section{Figure 2A-E}
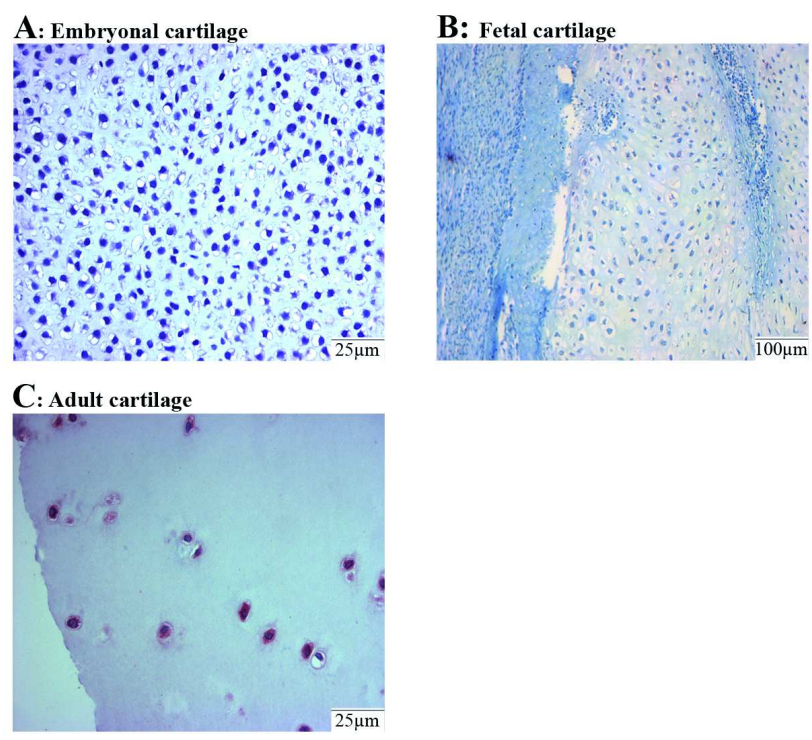

D: Chondrocyte primary culture
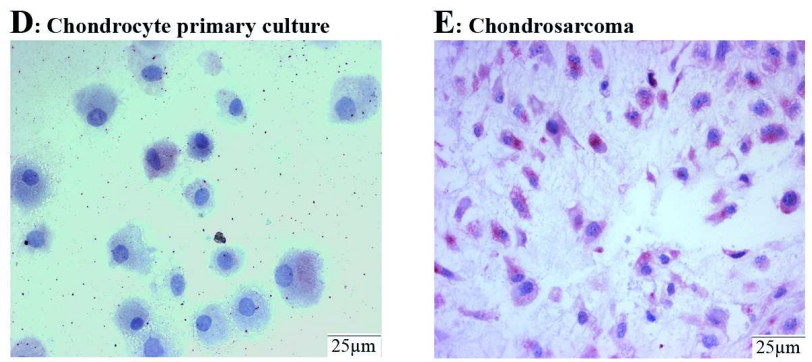

$210 \times 295 \mathrm{~mm}(200 \times 200 \mathrm{DPI})$ 


\section{Figure 3A-F}
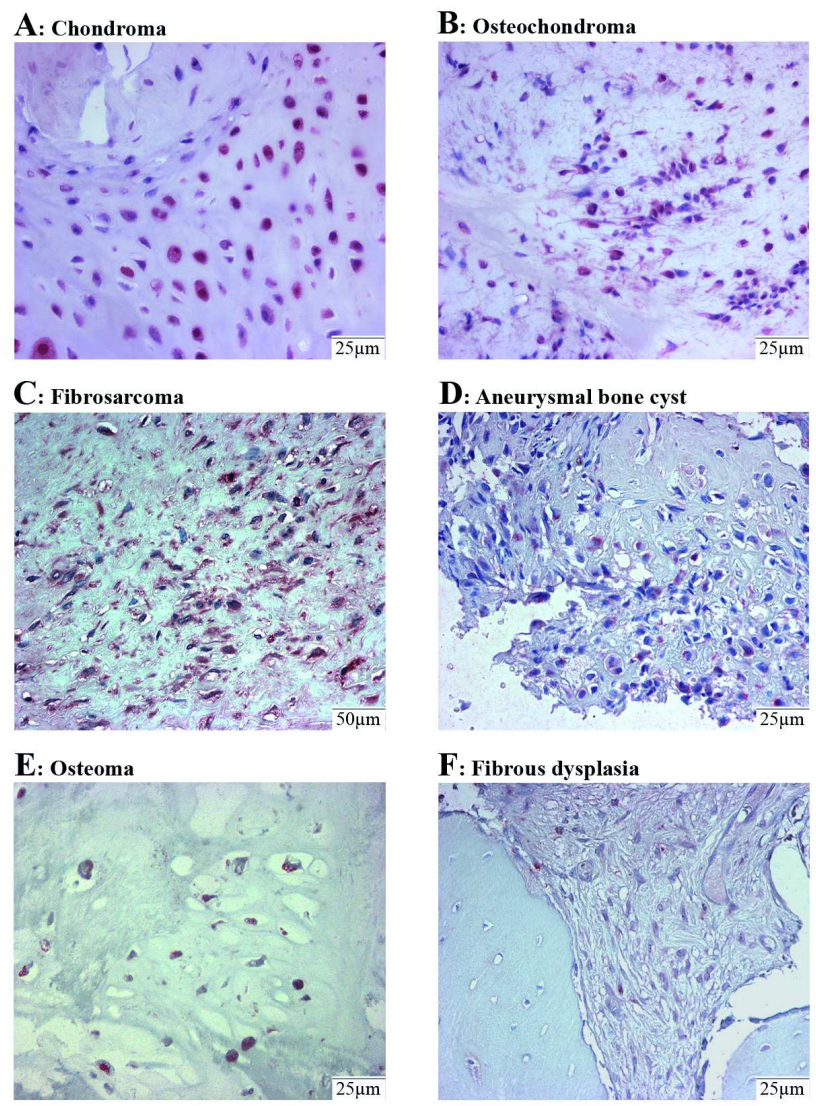

$210 \times 295 \mathrm{~mm}(200 \times 200 \mathrm{DPI})$ 


\section{Figure 4A-C}
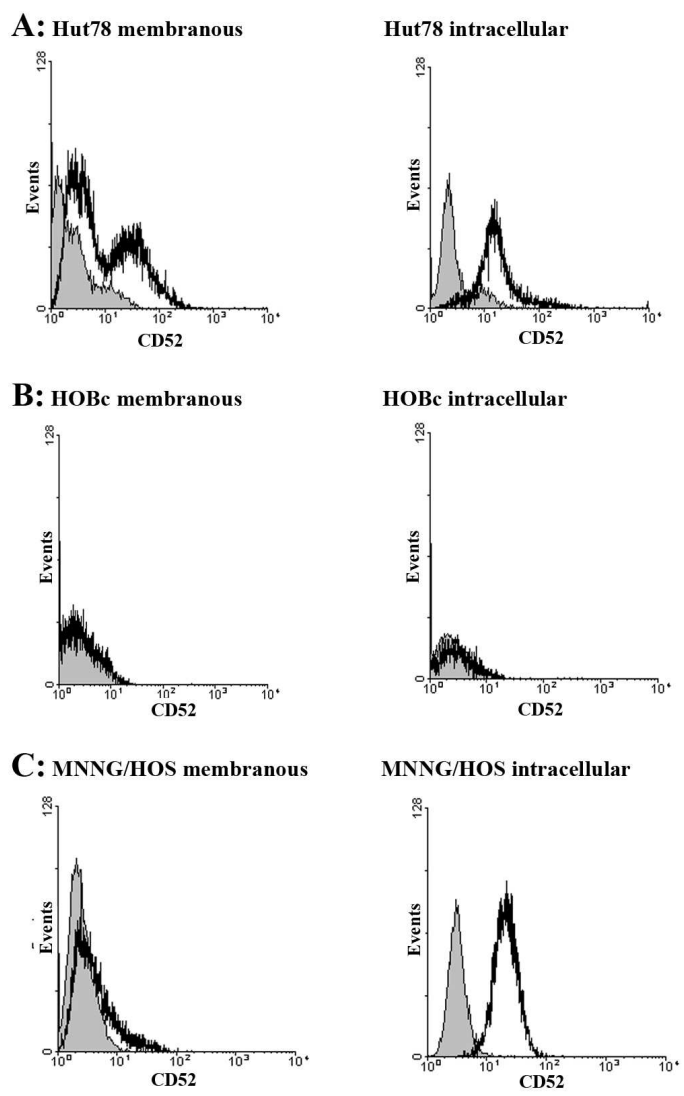

$210 \times 295 \mathrm{~mm}(200 \times 200$ DPI $)$ 


\section{Figure 4D-F}
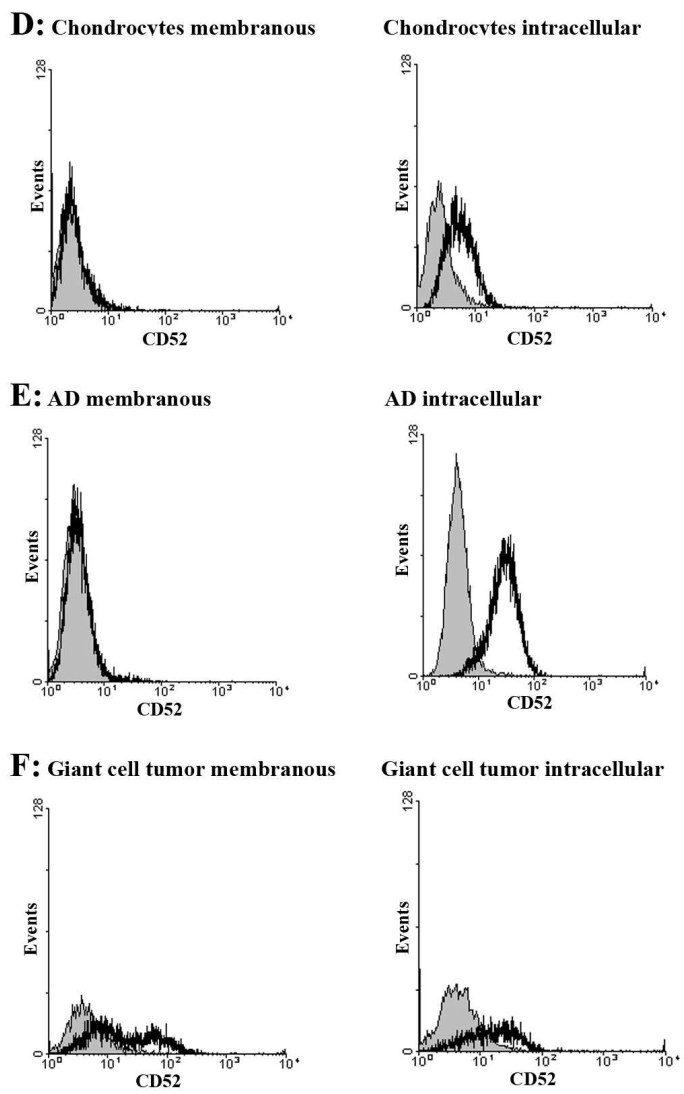

$210 \times 295 \mathrm{~mm}(200 \times 200 \mathrm{DPI})$ 
Figure 5A-C

A

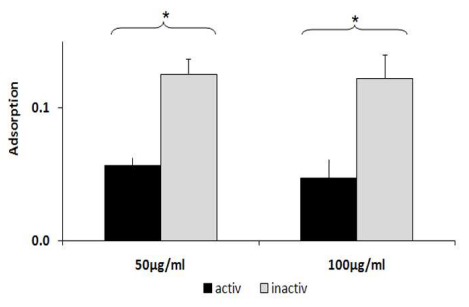

B

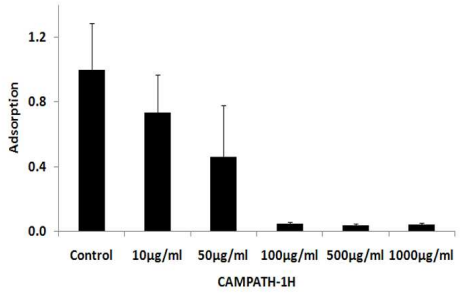

C

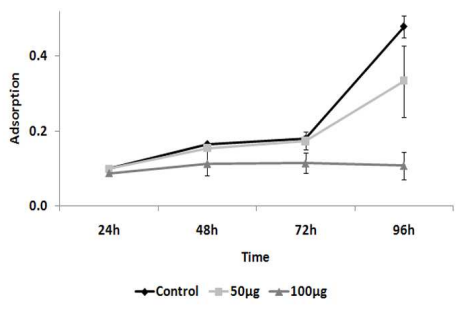

D

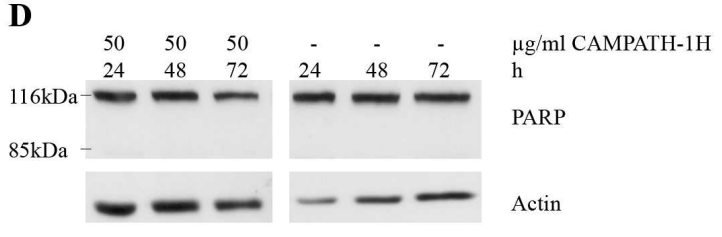

$210 \times 295 \mathrm{~mm}(200 \times 200$ DPI $)$ 


\section{Colour Work Agreement Form}

If you have any problems or queries please contact the Production Editor for guidance (details can be found in the Instructions for Authors)

If you have submitted a manuscript that contains colour figures. it is the policy of the journal for authors to meet the ful cost of coiour reproduction Blackwell Publishing require you to complete this form. Piease fill in your contact details and then comolete the table as instructed. Note: this form must be filled in for all manuscripts that have been subm tted wth colour work, even if you subsequently choose not to publish either in print or onilne in corour

We are unable to process your manuscript until we receive your instructions so please return this form as quickly as possible!

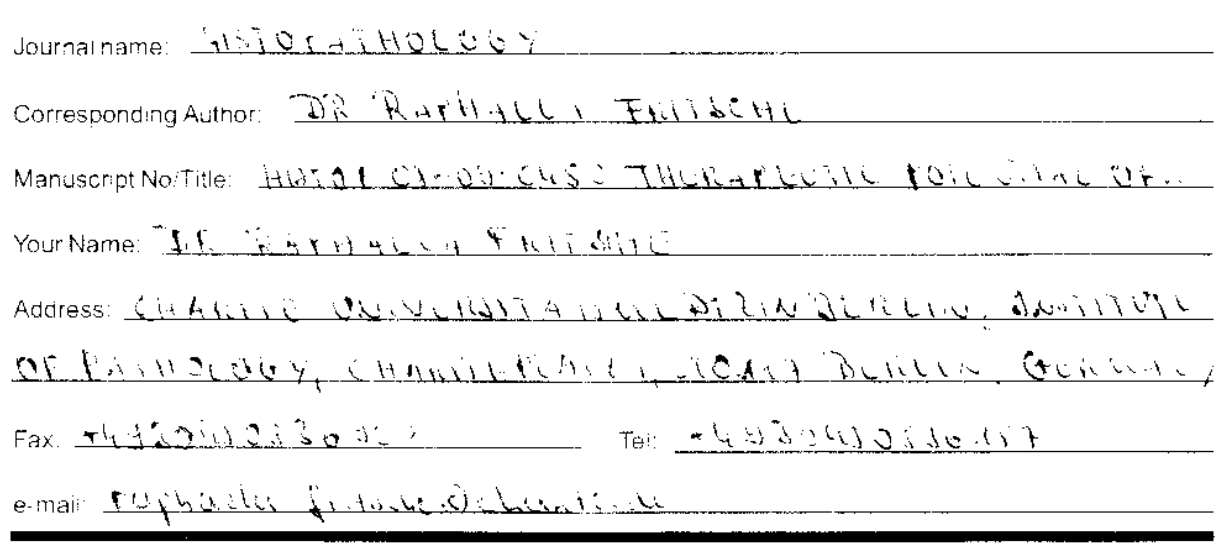

WHAT YOU NEED TO DO

Please complete the table on jage 2 placing an $X$ in the relevant coiumn for each figure The costs are shown at the top of each coiumn. Piease caiculate the totai cost for each category at the foot of the table, and then add VAT f apolcable (see below)

\section{All customers MUST quote their VAT numbers}

Customers in the UK: acd VAT at ' $75 \%$

Customers elsewhere in the EU:

- Customers regrstered for VAT No VAT (p ease complete details below)

VAT registration numoe:

Name of organisation

- Customers NOT regtstered for VAT: Acic VAT at $17.5 \%$.

Customers outside the EU: NO VAT

\begin{tabular}{|c|c|c|c|c|}
\hline \multicolumn{5}{|c|}{$\ll<$ For internal use ONLY $\gg>$} \\
\hline JPCMSNO & wounal acronym & volumie & Issue & Printrun \\
\hline
\end{tabular}


Please now complete this table (Remember: only one ' $X$ ' per figure).

\begin{tabular}{|c|c|c|c|}
\hline Figure Number & $\begin{array}{l}\text { Column } 1 \\
\text { Colour in print and online }\end{array}$ & $\begin{array}{l}\text { Column } 2 \\
\text { Colour online ONLY }\end{array}$ & $\begin{array}{l}\text { Column } 3 \\
\text { Błack \& white in print and ontine }\end{array}$ \\
\hline Costs & $\begin{array}{l}\text { ist ard 2nd figures = Free } \\
\text { Subsecuent foures }=\$ 60 \text { each }\end{array}$ & £50 oach & Free \\
\hline 1 & $x$ & & 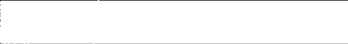 \\
\hline 2 & $x^{\prime}$ & & \\
\hline 3 & $x$ & & 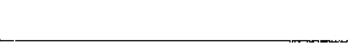 \\
\hline 4 & & & $x$ \\
\hline 5 & & & $x$ \\
\hline \multicolumn{4}{|l|}{6} \\
\hline \multicolumn{4}{|l|}{7} \\
\hline \multicolumn{4}{|l|}{8} \\
\hline \multicolumn{4}{|l|}{9} \\
\hline \multicolumn{4}{|l|}{10} \\
\hline $\begin{array}{l}\text { Total number of } \\
\text { figures of each tyoe }\end{array}$ & $\because$ & & $\Leftrightarrow$ \\
\hline
\end{tabular}

\begin{tabular}{|c|c|c|c|}
\hline \multicolumn{4}{|c|}{ 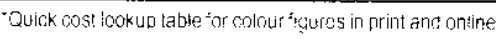 } \\
\hline No D: colou igs & Cost & No o cotour figgs & Cost \\
\hline$\therefore$ & Free & $\hat{\varphi}$ & 2240 \\
\hline 2 & Free & 7 & $£ 300$ \\
\hline 3 & 160 & 8 & 2360 \\
\hline 4 & $\hat{2} 120$ & 4 & $\$ 420$ \\
\hline 5 & f.18i & $\because$ & 2480 \\
\hline
\end{tabular}

\author{
Column 1 tota: $£ \stackrel{6}{\mathbf{c}}$ \\ Column 2 totai $£$ \\ VAT if apoilcabie) $₹$. . ( 5.5
}

Total: $\mathbf{f} 70$;

\section{Payment by Credit Card (MasterCard/VISA/American Express)}

Blackwel Pubishing accepts payment in three majo: currencies:

Pounds Sterling. United States Doilars and the Euro Please indicate wh:ch currency you would like to pay in

Pounds Stering ( $f$ ) $\square$ : United States Dol!ars* (US\$): Euros* (E)

"Conversions from US $\$$ or w $^{\prime}$ li be made at our monthly rate.

Please debit my credt card number: \begin{tabular}{|l|l|l|l|l|l|l|l|l|l|l|}
\hline \\
\hline
\end{tabular}

Verification ID Number: $\square+\square\left[\begin{array}{l}\square \\ \square\end{array}\right.$

Name on carc

Exp:ry Date

With the sum of

Signature

Date

Note: payment by credit card can oniy be accepted if all sections are compieted.

Please use BLOCK CAPITALS wnere possible

\section{Payment by Purchase Order}

If you are askıng your un!versity or institution to pay we require burchase orcee details

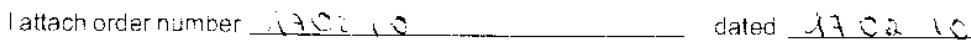

Please now return all pages of your completed form as a scanned electronic file (preferred option), or by fax or post to the production editor for your journal.

Contact details can be found in the instructions for authors. 